\title{
FATE OF INGESTED SODIUM BICARBONATE IN THE FOWL
}

\author{
J.-IR. HUNT \\ Canada Department of Agriculture (1), \\ Ottawa, Ontario (Canada)
}

\section{INTRODUCTION}

It has been shown by some workers, namely FRANK and BURGER (I965) and HowEs (I967), that the incorporation of sodium bicarbonate in the diet of the hen results in significant improvement in shell quality. FRANK and BURGER reported that a reduced level of dietary chloride was required to bring about the improvement of shell quality but Howes obtained a response in the presence of $0.4 \mathrm{p}$. Ioo $\mathrm{NaCl}$ in the diet with levels of supplemental $\mathrm{NaHCO}_{3}$ as low as 0.125 p. IoO.

PEPper ct al. (Ig68) noted that the addition of o.I p. Ioo $\mathrm{NaHCO}_{3}$ to a diet containing 0.25 p. IOO NaCl (0.05 p. IoO higher in $\mathrm{NaCl}$ than that used by Frank and Burger) had no effect on shell quality. Similarly, Morris (Ig66) found that the addition of 0.5 p. I $00 \mathrm{NaHCO}_{3}$, in diets of low chloride content, had no effect on shell quality as measured by weight of the shell per unit area. Work in this laboratory, as yet unpublished, has shown that a response in shell quality was not obtained to the addition of $\mathrm{NaHCO}_{3}$ to the laying diet. These diets contained $0.175 \mathrm{p}$. Ioo added $\mathrm{NaCl}$ and had supplemental levels of $0.2,0.4$ and 0.6 p. Ioo $\mathrm{NaHCO}_{3}$.

The lack of response may be due to the $\mathrm{NaHCO}_{3}$ being converted to $\mathrm{CO}_{2}$ and expelled through the lungs. The entire digestive tract of the fowl is acidic in nature (FARNER, I942; HERPOL, I966) and would be unfavourable for sodium bicarbonate to exist in the ionic form. From the results of in vivo measurement of crop pH (HERPOL, I966) it would appear that most of the salt would be converted into carbon dioxide in this portion of the digestive tract.

The object of the work reported here is to determine if presence of $\mathrm{NaHCO}_{3}$ in the diet affects the $\mathrm{pH}$ of the digestive tract and to determine the fate of ingested $\mathrm{NaHCO}_{3}$.

( ${ }^{1}$ Contribution Number 380 from the Animal Research Institute, Ottawa, Ontario (Canada). 


\section{MATERIALS AND TECHNIQUES}

The first experiment was designed to determine the effect of $\mathrm{NaHCO}_{3}$ and $\mathrm{CaCO}_{3}$ on the $\mathrm{pH}$ of the digestive tract. The four rations described in table I were fed to 4 groups of 9 birds each for a period of 4 weeks. The experiment was repeated 3 times. Rations $\mathrm{I}$ and 2 contained I.85 p. Ioo calcium while rations 3 and 4 contained 3.85 p. roo calcium. Sodium bicarbonate was added at a level of 0.5 p. Ioo to rations 2 and 4 . At the end of the 4 week period the birds were anæsthetized with pentobarbitol-sodium administered via the brachial vein. After the birds were in deep anæesthesia, the digestive tract was exposed and the $\mathrm{pH}$ of segments measured with a combined electrode (tip $=65 \times 7 \mathrm{~mm}$ ) in conjunction with a Model E3oo Metrohm pH-meter. The proventriculus was entered through the gizzard. The duodenum was entered at the top of the loop and the electrode tip immersed its full length down the posterior side of the loop. The

TABLE I

Composition of experimental ration

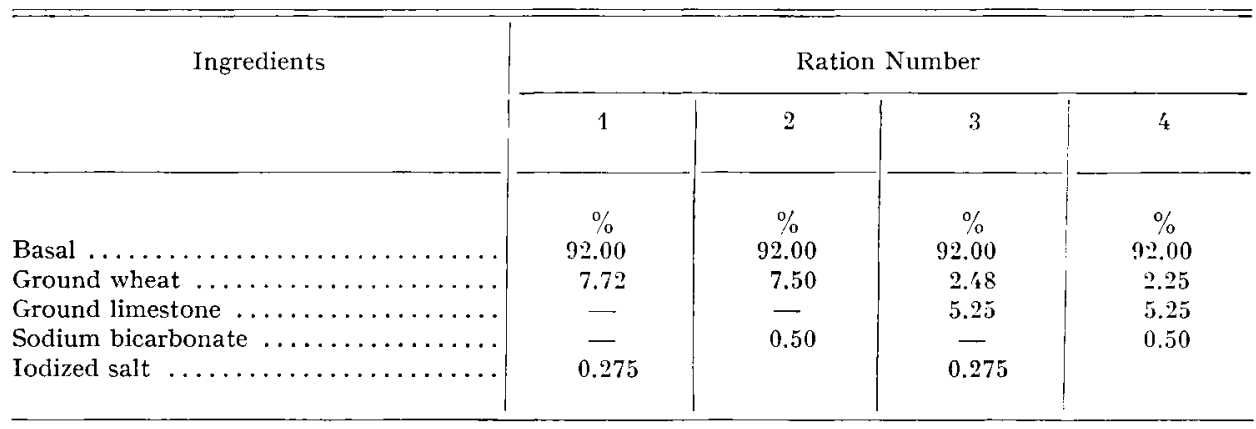

Basal Ration

Ingredients $\%$

\begin{tabular}{|c|c|}
\hline Groul & \\
\hline Ground wheat & 33.5 \\
\hline$\ldots \ldots \ldots \ldots \ldots \ldots \ldots$ & 20.0 \\
\hline$\ldots \ldots \ldots \ldots \ldots \ldots \ldots \ldots$ & 10.0 \\
\hline I ish meal $(65 \%$ prot. $) \ldots \ldots \ldots \ldots \ldots \ldots$ & 2.0 \\
\hline Meat meal $(55 \%$ prot. $) \ldots \ldots \ldots \ldots$ & 2.0 \\
\hline Soybean oil meal $(44 \%$ prot. $) \ldots \ldots \ldots \ldots \ldots$ & 5.0 \\
\hline Skim milk powder $\ldots \ldots \ldots \ldots \ldots \ldots \ldots \ldots$ & 1.5 \\
\hline Dehydrated alfalfa meal $\ldots \ldots \ldots \ldots \ldots \ldots \ldots$ & 3.0 \\
\hline Steamed bone meal $\ldots \ldots \ldots \ldots \ldots \ldots \ldots \ldots$ & 1.25 \\
\hline Ground limestone $\ldots \ldots \ldots \ldots \ldots \ldots \ldots$ & 3.50 \\
\hline Iodized salt $\ldots \ldots \ldots \ldots \ldots \ldots \ldots \ldots \ldots \ldots \ldots$ & 0.10 \\
\hline Micro ingredients $\left({ }^{1}\right)$.. & 0.15 \\
\hline & $\overline{92.00}$ \\
\hline
\end{tabular}

(') Supplied vitamin A, 60,000 IU ; vitamin $\mathrm{D}_{3}, 67,000 \mathrm{ICU}$; riboflavin, 220 ; and manganese sulfate, $5.7 \mathrm{gm}$ per $100 \mathrm{lb}$. feed. 
mid-intestinal reading was taken with the incision at approximately the mid point and the tip was immersed posteriorly to its full length. An incision was made at the coecal-intestinal junction and the electrode immersed full length in an anterior and posterior direction. Measurement of crop $\mathrm{pH}$ was not taken in this experiment.

The second experiment was concerned with the use of carbon labeled $\mathrm{NaHCO}_{3}$ to follow the passage of the bicarbonate in the fowl. A hen was placed in a gas tight chamber, (40 $\times 18 \times 35 \mathrm{~cm})$ having just received $5 \mu \mathrm{Ci}$ of $\mathrm{NaH}^{14} \mathrm{CO}_{3}$ in the crop by means of a pipette. By means of a vacuum pump, air was pulled through the chamber, through a drying column and then through a series of three traps containing $50 \mathrm{ml}$ of molar hydroxide of hyamine in methanol as shown in figure $\mathrm{I}$.

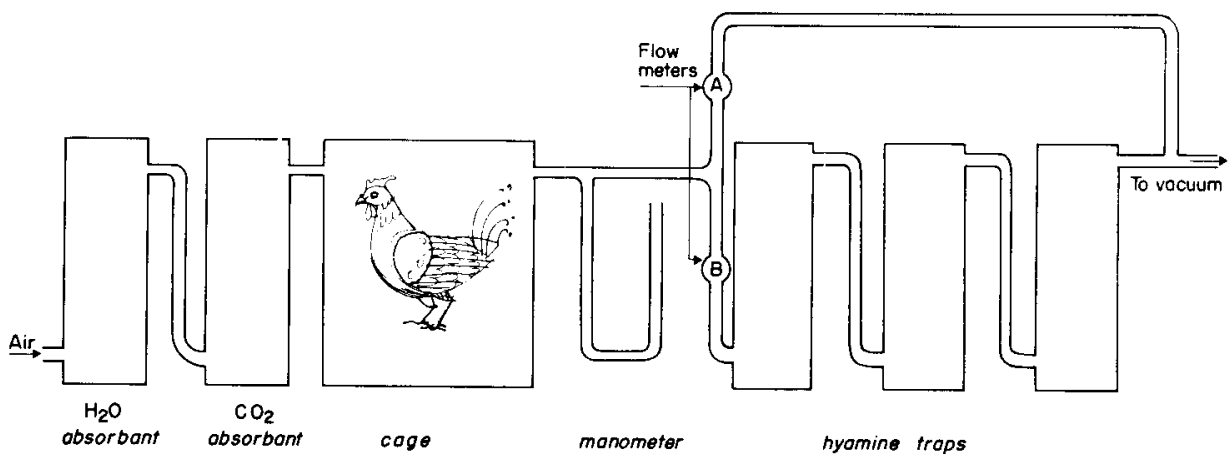

A system of flowmeters and valves allowed $5 \mathrm{p}$. Ioo of the air drawn through the system to be passed through the hyamine traps. A $0.5 \mathrm{ml}$ sample of hyamine was drawn from the traps at I 5 minute intervals for a period of 5 hours. The samples were counted by liquid scintillation using $4 \mathrm{~g}$ of omnifluor per liter of toluene. This procedure was carried out on six birds.

Six birds were also given the same dose of labeled $\mathrm{NaHCO}_{3}$ and held in the chamber for I hour under similar conditions of negative pressure. On removal they were killed by an overdose of an intravenous injection of pentabarbitol sodium. The cesophagus was clamped off with hæmostats to prevent drainage from the crop and the digestive tract ligated off at the crop, proventriculus, gizzard and duodenum. Each section of gut had $2 \mathrm{ml}$ of $0.2 \mathrm{~N} \mathrm{NaOH}$ injected into the lumen. When the section of gut was removed the contents were washed out with an additional $8 \mathrm{ml}$ of $0.2 \mathrm{~N} \mathrm{NaOH}$ into a reaction vessel. An excess of $\mathrm{HCl}$ was added to the reaction flask and the evolved $\mathrm{CO}_{2}$ was trapped in hyamine and counted as previously described.

Six birds on a low (o. 6 p. Ioo added $\mathrm{NaCl}$ ) and six on a normal (o.4 p. I oo added $\mathrm{NaCl}$ ) chloride diet were given the same dose of $\mathrm{NaH}^{14} \mathrm{CO}_{3}$, in the manner described above, when there was a hard shelled egg in the shell gland. The birds were returned to their individual cages and allowed to have a normal oviposition. If the egg was laid four to six hours after the administration of the labeled bicarbonate, the contents of the egg were discarded, the membranes washed with tap water and the shell dried to constant weight. The shell was broken into small pieces and placed in a reaction flask with $20 \mathrm{ml}$ of distilled water and $0.2 \mathrm{ml}$ of octanol- $\mathrm{I}$. An excess of $\mathrm{HCl}$ was added and the evolved $\mathrm{CO}_{2}$ trapped as previously described.

\section{RESULTS}

\section{Effect of diet on digestive tract $p H$}

The mean $\mathrm{pH}$ value with their respective S.E.M. for the various segments of the digestive tract are given in table 2 . The values are slightly basic compared to one report (HERPOL, I966) but are more acid in the upper region of the tract when compared with the results of FARNER (I942). Analyses of variance of the results (table 3) 
indicates that diet does influence digestive tract $\mathrm{pH}$. Sodium bicarbonate at the $0.5 \mathrm{p}$. I oo level had no effect on $\mathrm{pH}$, however, calcium carbonate had a highly significant effect when fed at the high level. In both the proventriculus and the gizzard the feeding of the high calcium carbonate diet resulted in a reduced acidity. This

TABLE 2

Mean digestive tract pH values with S. E. M.

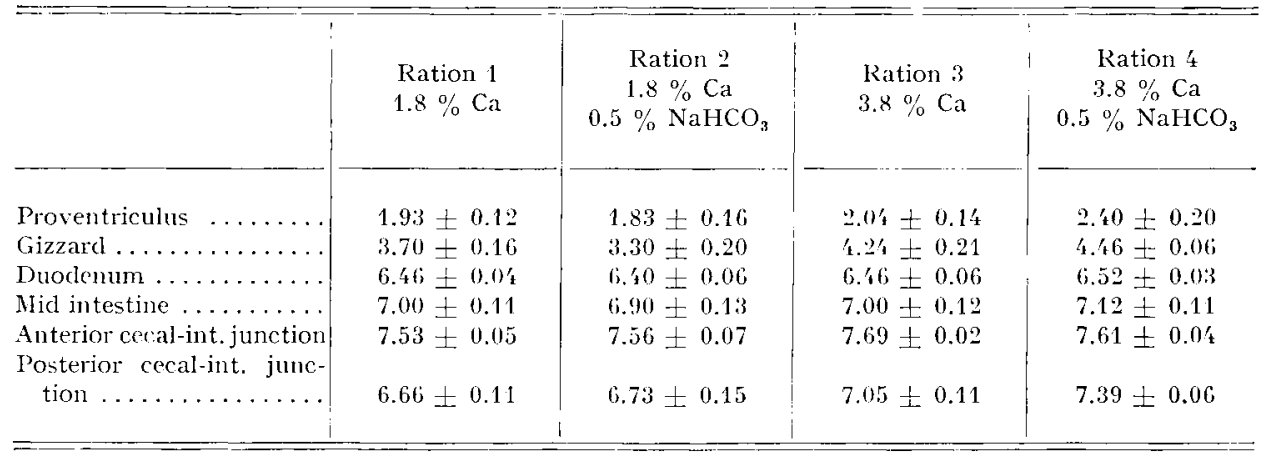

effect was not evident in the remainder of the tract until the $\mathrm{pH}$ was taken in a posterior direction from the creal-intestinal junction. Again, the feeding of the high calcium carbonate diet had in alkalizing effect of the gut contents.

There were no interactions between bicarbonate and calcium carbonate for the various segments of the gut when $\mathrm{pH}$ was measured.

\section{Fate of ingested $\mathrm{NaH}^{14} \mathrm{CO}_{2}$ in the laying hen}

Sampling the expelled air from the bird indicated that the majority of the labeled $\mathrm{CO}_{2}$ is expired by $\mathrm{I}_{\mathrm{S}} 5$ hours. A typical graph of the radioactivity of the first and second trap is given in figure 2 . In all cases labeled $\mathrm{CO}_{2}$ was expelled in negligible amounts after 2 hours. This was checked by placing fresh traps in the line after the bird had been in the chamber for 2 hours. In an additional 2 hours of collection only 20000 counts $/ \mathrm{mn}$ were trapped out of 4.8 million count $/ \mathrm{mn}$. An estimate of the percentage of counts, trapped in expired air, of the total dose indicated some $9 \mathrm{I}-$ 94 p. Ioo of the radioactivity was accounted for in the expired air. An account of all the radioactivity could not be made in this test as fecal and residual body ${ }^{14} \mathrm{CO}_{2}$ were not measured. Also the system employed flowmeters and stopcocks to partition the gas stream and this system has some error associated with it as variation in flow rates was noted throughout the experiments.

Counts of radioactivity in the contents of the gut segments indicated that, after I hour after administering the tracer, the crop contained 84.34 p. roo \pm 6.79 S.E. of the total activity found in the gut while the proventriculus, gizzard and duodenum had $8.26 \pm 3.78,6.96 \pm 3.29$ and 0.67 p. Ioo \pm 0.35 S.E. respectively. The total activity found in the gut was, on the average, equivalent to $0.7 \mathrm{p}$. I00 of the activity administered I hour earlier. 


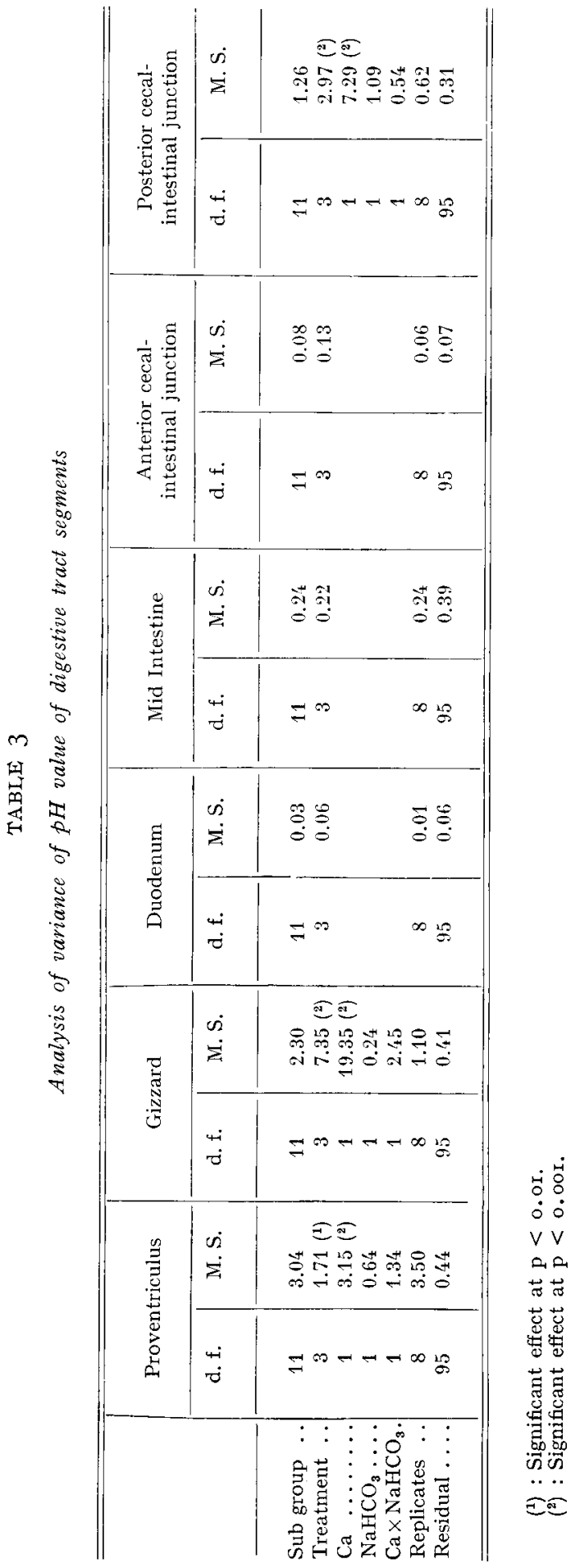


The activity of the egg-shell, when the tracer was administered in crop 4 to 6 hours prior to oviposition, was found to be low. The type of diet had no effect on the uptake of activity as the mean counts/mn for the birds on the low and normal chloride was $3.4 \pm 0.3$ and $2.7 \pm 0.4 \mathrm{SE}$ of the total counts/mn respectively. This latter point was tested by the $t$ test.

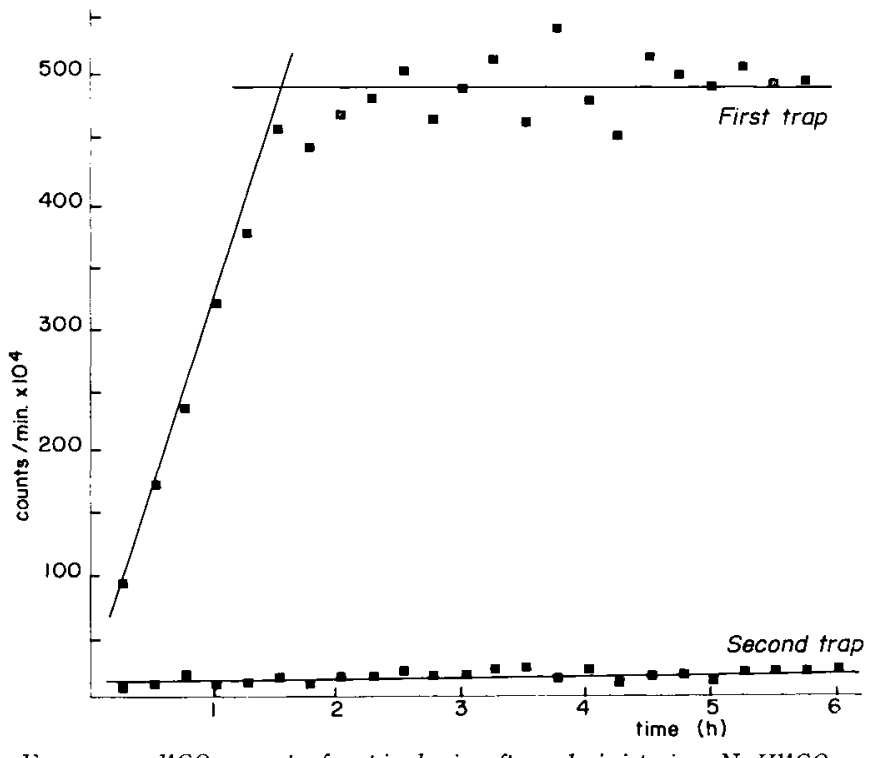

Fig. 2. - ${ }^{14} \mathrm{CO}_{2}$ count of expired air after administering $\mathrm{NaH}^{14} \mathrm{CO}_{3}$ in the crop of the laying hen

\section{DISCUSSION}

The lack of effect of $\mathrm{NaHCO}_{3}$ on the acidity of the proventriculus and gizzard is not surprising since the glandular stomach has considerable ability to secret $\mathrm{HCl}$ although it has been noted (MUSSEHL et al., I933) that higher levels reduce the $\mathrm{pH}$ (STURKIE, I965). The effect of the calcium carbonate had been noted earlier (FARNER, I943). It is common practice to feed 5 to $7 \mathrm{p}$. Ioo calcium carbonate in poultry feeds to improve shell quality. The action of this material is known to be not through the contribution of calcium (HuRwitz and Griminger, I962) but the exact mode of action is not known. Speculation of its contribution to provide for the carbonate portion of the shell should await further experimentation.

The rapid expulsion of labeled $\mathrm{CO}_{2}$ from bicarbonate placed in the crop, through the respiratory system, may explain the difference in response obtained by the various research workers. Since the shell is formed, for a great part, in a period when the bird is not consuming feed, one would expect that there is little bicarbonate to contribute to shell formation as most of it would be expelled through the respiratory system quite rapidly. However, if the blood is capable of retaining more $\mathrm{CO}_{2}$, as it would under hyperventilation, then bicarbonate in the feed may provide this gas and it may be retained for longer periods. 
These experiments do not provide firm evidence but suggest that the bicarbonate is absorbed from the crop. The crop appears to play a very minor role in the absorption of the nutrients (STURKIE, 1965) however, the acidic nature of the crop should convert most of the bicarbonate to the gas state which would pass through the crop wall.

The fact that activity appears in the egg shell indicates that dietary bicarbonate contributes to shell formation. In this experiment the level of chloride in the diet did not influence the amount of labeled carbon that appeared in the egg shell but it must be remembered that the number of experimental birds employed in these experiments was very limited. Further research is required in this area.

\section{SUMMARY}

The addition of 0.5 p. Ioo sodium bicarbonate de sodium to the diet of the laying hen had no effect on the $\mathrm{pH}$ of the proventriculus, gizzard, duodenum, small intestine or large intestine. The addition of $5.25 \mathrm{p}$. I 00 calcium carbonate to the basal diet significantly increased $\mathrm{pH}$ in the proventriculus, gizzard and large intestine. There was no interaction between sodium bicarbonate and calcium carbonate on digestive tract $\mathrm{pH}$.

When ${ }^{14} \mathrm{C}$ labeled sodium bicarbonate was introduced into the crop, it was found that the total amount of labeled material expelled as $\mathrm{CO}_{2}$ in expired air was complete in $\mathrm{I} .5$ hours. If the digestive tract was ligated I hour after the administration of the tracer only $0.7 \mathrm{p}$. Ioo of the dose was found in the tract and $84 \mathrm{p}$. Ioo was present in the crop. The amount of tracer found in the shell when the tracer was administered 4 to 6 hours prior to oviposition was 3.4 p. Ioo and 2.7 p. Ioo of the total dose for low chloride and normal chloride diets respectively. These differences were not significant.

\section{RÉSUMÉ}

\section{DEVENIR DU BICARBONATE DE SODIUM INGÉRÉ CHEZ IA POULE}

L'addition de $0,5 \mathrm{p}$. Ioo de bicarbonate de sodium dans le régime de poules pondeuses n'a aucune influence sur le $\mathrm{pH}$ du proventricule, du gésier et de l'intestin. L'addition de 5,25 p. roo de carbonate de calcium dans le régime de base augmente d'une manière significative le pH du proventricule, du gésier et du gros intestin; il n'y a pas d'interaction entre le bicarbonate de sodium et le carbonate de calcium sur le pH du tube digestif.

Lorsque du bicarbonate de sodium radioactif $\left({ }^{14} \mathrm{C}\right)$ est introduit dans le jabot, on constate que la radioactivité maximale sous forme de $\mathrm{CO}_{2}$ expiré est atteinte après une heure et demic. En cas de ligature du tube digestif une heure après l'administration du radioisotope, on constate que 0,70 p. Ioo seulement de la dose est présente dans le tube digestif alors que 84 p. Ioo de la radioactivité se retrouve dans le jabot. Lors de l'administration du radioisotope 4 à 6 heures avant l'oviposition, la radioactivité trouvée dans la coquille représente 3,4 et $2,7 \mathrm{p}$. I 00 de la dose originale pour des régimes dont la teneur en chlore est respectivement faible ou normale; la différence entre ces valeurs n'est pas significative.

\section{REFERENCES}

Farner D. S., I942. The hydrogen-ion concentration in avian digestive tracts. Poultry Sci., 21, 445450.

FARner D. S., 1943. The effect of certain dietary factors on gastric hydrogen ion concentration and acidity in the domestic fowl. Poultry Sci., 22, 295-298.

Frank F. R., BURGer R. E., 1965. The effect of carbon dioxide inhalation and sodium bicarbonate ingestion on egg shell deposition. Poultry Sci., 44, I604-1606. 
Herpol C., I966. Influence de l'àge sur le $\mathrm{pH}$ dans le tube digestif de Gallus domesticus. Ann. Biol. anim. Bioch. Biophys., 6, 495-502.

Howls J. R., I967. Acid-base relationships and calcium deposition in the egg shell. Proc. Dist. Feed Res. Conf., 22, 29-36.

Hurwitz S., Griminger P., ig62. Estimation of calcium and phosphorus requirement in laying hens by balance techniques. J. Sci. Food A gric., 13, 185-191.

Morris T. R., I966. Personal communication.

Mussehl F. E., Blish M. J., Ackerson C. W., 1933. Effect of dietary and environmental factors on the $\mathrm{pH}$ of the intestinal tract. Poultry Sci., 12, I20-123.

Pepper W. F., Summers J. D., McConachie J. D., Ig68. The effect of high levels of calcium, fish products and sodium bicarbonate on egg shell quality. Poultry Sci., 47, 224-229.

Sturkie P. I)., I965. Avian Physiology. Comstock, Ithica, New York. 